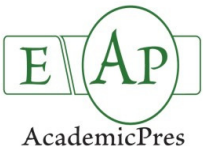

\title{
Developmental and Cytochemical Features of Male Reproductive Organ in Crataegus tanacetifolia (Lam.) Pers.
}

\author{
Aslıhan ÇETINBAŞ*, Meral ÜNAL \\ MarmaraUniversity, DepartmentofBiology, 34722, Istanbul,Turkey; aslihancetinbas1@hotmail.com (*orrespondingauthor); meralunal@marmara.edu.tr
}

\begin{abstract}
In this study, the development of male reproductive organ was analysed in Crataegus tanacetifolia (Lam.) Pers., endemic to Turkey. Androecium is composed of 20 stamens which are attached at the base of the filaments. The anther wall formation follows the dicotyledonous type. The undifferentiated anther is ovoid-shaped, and the differentiation starts with the appearance of archesporial cells. Mature anthers are dorsifix and tetrasporangiate. The anther wall is composed of an epidermis, endothecium, two or three rows of middle layers and secretory tapetum. Endothecial cells show fibrous thickening. Tapetum is characterized by enlarged secretory types with binucleate cells, which presented an intense reaction with regard to proteins, insoluble polysaccharides and lipids. Features of chromatin condensation and nucleus disorders identified with the application of DAPI ( $4^{\prime}, 6$-diaminido-2-phenylindole) point out programmed cell death. Epidermal and endothecial layers remain intact until anther dehiscence; however, middle layer and tapetum disappear during development. At the end of regular meiotic division, tetrahedral microspore tetrads are formed. Pollen grains are tricolparatae, tectate and sphaeroidea. Exine is made up of lipoidal substances and proteins, but the intine includes insoluble polysaccharides. Further, cytoplasm of pollen grains are rich in proteins, lipids and insoluble polysaccharides.
\end{abstract}

Keywords: anther ontogeny, anther wall, microsporogenesis, Rosaceae

\section{Introduction}

Crataegus tanacetifolia (Lam.) Pers. belongs to genus Crataegus of the subfamily Maloideae of Rosaceae (Campbell et al., 2007). According to Davis and Browicz (1972), there are 17 species, one subspecies and a few varieties of Crataegus, which grow naturally in Turkey. $C$. tanacetifolia is an important endemic species to Turkey and widely spreads in Bolu, Karabük, Kastamonu and Ankara. C. tanacetifolia is economically valuable plant for having edible fruits.

Morphological characters of the male gametophyte and details of microsporogenesis are useful in taxonomic studies for defining the circumscription of taxones. There are some taxonomically important characters such as; variability in the number of anther layers, thickening in endothecium, number of rows in middle layer, arrangement of tetrads within the callosic wall, number of pollen pores or colpes and bi or tricellular pollen grains (Galati et al., 2006; Gotelli et al., 2006; Liu and Huang, 2003). Additionally, the number of tapetum and the type of tapetum have taxonomic value in the sense that all members of most angiosperm families have the same type (Davis, 1966; Johri et al., 1992).

Two main types of tapetum are recognized in plants; secretory and amoeboid type. Secretory type is considered to be the prevalent type in majority of plants. The tapetal cells remain accompanied with the anther wall until their degeneration and secrete substances to the anther locule. Four types of anther wall development were described by Davis (1966) based on the secondary parietal layers: basic type, dicotyledonous type, monocotyledonous type and reduced type. Many authors use this classification to explain anther wall ontogeny (Aybeke, 2012; Bittencourt, 1996; Chehregani et al., 2008; Garcia, 2002; Hardy and Stevensen, 2000; Liu and Huang, 2003; Strittmatter et al., 2000).

The present research is the first study on the male reproductive organ of $C$. tanacetifolia (Lam.) Pers., endemic to Turkey. This paper provides knowledge on anther ontogeny, anther wall development, microspore development, pollen morphology and cytochemical features; by the application of light, fluorescence and scanning electron microscopy. Information on the development of male reproductive organ will help advance our understanding of reproductive behaviour and will thus contribute to attempts to solve taxonomic problems in Crataegus, a rather neglected genus in this respect.

\section{Materials and Methods}

Material and morphological analysis

Flower buds of $C$. tanacetifolia were collected from Bolu, Lake Abant Nature Park (Turkey), and flowers were morphologically analysed and picked under stereomicroscope (Olympus 970931). 
508

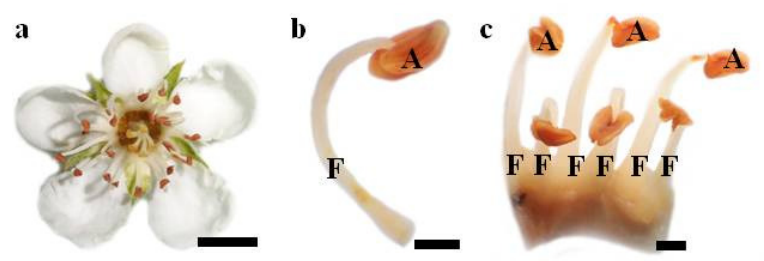

Fig. 1. Stereomicrograph of androecium in C. tanacetifolia. a. Flower of C. tanacetifolia. b. Mature stamen. c. Stamens which associated from bottom of the filament. A: Anther, F: Filament. Bar: 5 mm (a), 1 mm (b,c).

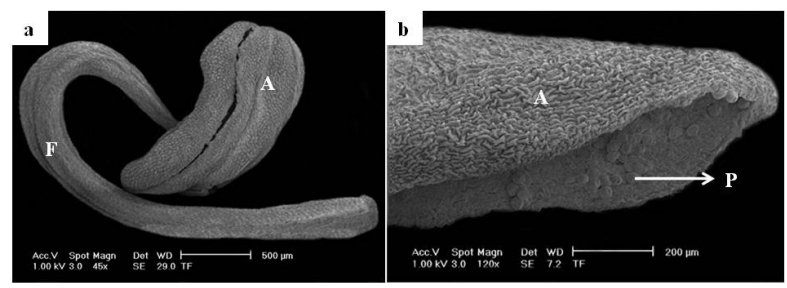

Fig. 2. SEM photomicrograph of a stamen in C. tanacetifolia. a. Mature stamen. b. Anther dehishence. A: Anther, F: Filament, P: Pollen grain. Bar: $500 \mu \mathrm{m}(\mathrm{a}), 200 \mu \mathrm{m}$ (b)

\section{Light and fluorescence microscope analysis}

Stamens were carefully excised and fixed in glacial acetic acidalcohol and FAA (Formalin-glacial acetic acid-alcohol) solutions, and they were embedded in paraffin. Ultimately, they were sliced at $5-10 \mu \mathrm{m}$ by Leica RM2235 rotation microtome. Sections were stained with Delafield's hematoksilin.

For cytochemical analysis, sections were stained with periodic acid-Schiff (PAS) (Feder and O’Brien, 1968) for insoluble polysaccharides, Coomassie Brilliant Blue (Fisher et al., 1968) for proteins, Sudan Black B for lipids (Pearse, 1961) and Auramine O (Heslop-Harrison and Shivanna, 1977) for exine. For investigation of nucleus disorders, sections were stained with DAPI (4',6-diaminido-2-phenylindole) (Schweizer, 1976).

For ultrastructural studies, stamens were fixed in Karnowsky fixative (5\% glutaraldehyde and $4 \%$ paraformaldehyde) and embedded in epoxy resin. Next, ultrathin sections $(\sim 70 \mathrm{~nm})$ were cut using a Leica Ultracut $\mathrm{R}$ and stained in $1 \%$ Toluidine blue (O’Brien et al., 1964).

The preparations were photographed with an Evolution LC color camera and attached to an Olympus BH-2 light microscope, and the images were analyzed though Image-Pro Express Version 6.0 scientific image processing and analysis software. Auramine $\mathrm{O}$ and DAPI preparations were investigated by Leica DM LB2 fluorescence microscope at respectively 440 $\mathrm{nm}$ and $365 \mathrm{~nm}$ wavelengths and photographed by Leica DFC 329 fluorescence camera.

\section{Scanning electron microscope (SEM) analysis}

For the study of anther and pollen morphology by SEM analysis, the material was fixed in $2.5 \%$ glutaraldehyde in 50 $\mathrm{mM}$ cacodylate buffer, $\mathrm{pH} 7.0$ (Platt et al., 1983) and then dehydrated with an increasing ethanol gradient: from $70 \%$ up to $100 \%$. Subsequently, the material for drying were kept in HMDS (hexamethyldisilazane) solution at room temperature (Topçuoğlu et al., 2009) and coated with $11 \mathrm{~nm}$ of gold by
Table 1. Relation between anther length and developmental stage in $C$. tanacetifolia (20 anthers were measured)

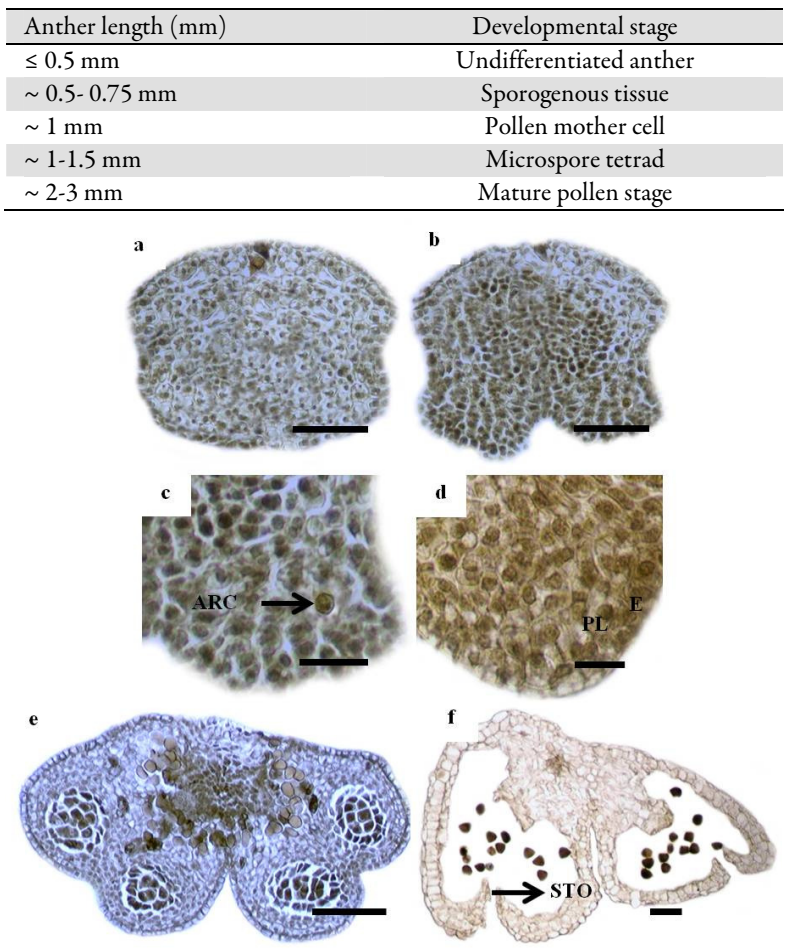

Fig. 3. Ontogeny of an anther in transverse sections of C. tanacetifolia. a. Undifferentiated anther. b. The anther becomes slightly lobed. c. Archesporial cell with prominent nucleus and dense cytoplasm. d. Parietal layer (toward the outer side) and epidermis. e. General view of tetrasporangiate anther. f. Mature anther with stomium. ARC: Archesporial cell, E: Epidermis, PL: Parietal layer, STO: Stomium. Bar: $50 \mu \mathrm{m}(\mathrm{a}-\mathrm{d}), 100 \mu \mathrm{m}(\mathrm{e}-\mathrm{f})$

using an automated sputter coater and then examined with a SEM (JEOL JMS-59 10LV).

\section{Results}

\section{Structure of the androecium}

Androecium of C. tanacetifolia consists of 20 stamens (Fig. 1a) which attached at the base of the filaments (Fig. 1c). Mature stamens are 5-8 $\mathrm{mm}$ in length and filaments are longer than the anthers (Fig. 2a). Mature anthers are yellow-brown, dorsifix and tetrasporangiate (Fig. 1b). Pollen grains are released by dehiscence of stomium (Fig. 2b).

\section{Anther ontogeny and anther wall development}

The developmental processes in the anthers of $C$. tanacetifolia are classified into four stages: sporogen tissue, pollen mother cells (PMCs), microspore tetrad and mature pollen stage. Anther wall development and microsporogenesis were investigated according to this classification. The relation between anther length and developmental stages is presented in Table 1.

The undifferentiated anthers of C. tanacetifolia are ovoid, containing meristematic cells encircled by an epidermal layer (Fig. 3a). Differentiation starts in each sporangium by the occurrence of 


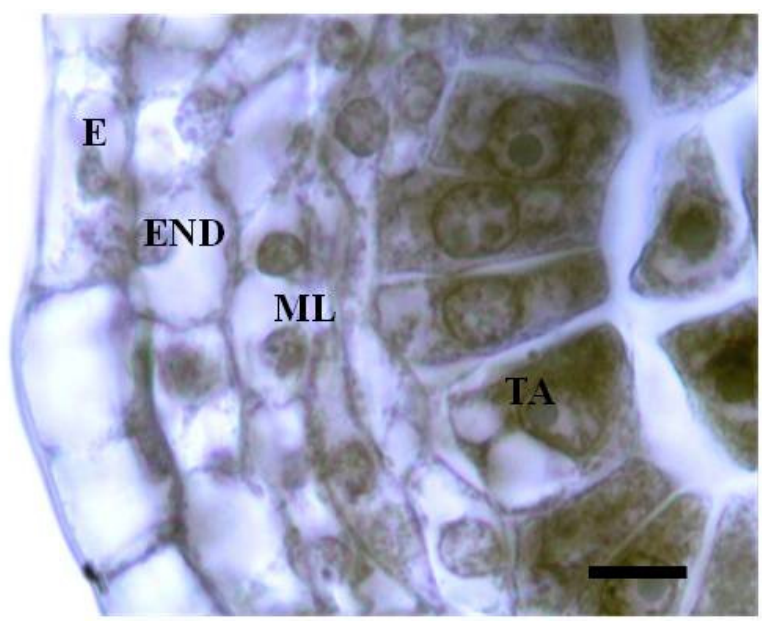

Fig. 4. Anther wall layers of $C$. tanacetifolia. E: Epidermis, END: Endothecium layer, ML: Middle layer, TA: Tapetum. Bar: $10 \mu \mathrm{m}$

the archesporial cells (Fig. 3b). They have prominent nuclei and dense cytoplasm which make them distinguishable from rest of the cells (Fig. 3c). The archesporial cells undergo periclinal divisions forming the primary parietal layer towards the epidermis and the sporogenous layer to the connective site (Fig. 3d). The cells of the parietal layer form concentric layers of wall endothecial, middle and tapetal layer (dicotyledonous type) by a series of periclinal and anticlinal divisions. At this time, the sporogenous cells enlarge and undergo mitotic divisions once generating pollen mother cells (PMCs). The anthers enlarge during the development, and they become tetrasporangiate (Fig. 3e). At the end of the development, mature pollen grains are released by dehiscence of stomium (Fig. $3 \mathrm{f}$ and Fig. 2b).

\section{Structure and development of the anther wall}

The anther wall of $C$. tanacetifolia consists of four layers from outer to inner: an epidermis, endothecium, two or three row of middle layers and a layer of tapetum (Fig. 4). Anther wall development is dicotyledonous. The middle layer and endothecium layer share the same origin. Initially, four wall layers have similar shapes and sizes.

Epidermis consists of single row of rectangle, flattened and ordered cells (Fig. 5a). It does not include trichomes and stomas. At the beginning of the development, epidermal cells remain small (Fig. 5a). Concurrent with the progression of meiosis in PMCs, the epidermal cells grow and tangentially elongate (Fig. 5c). As from tetrad stage, epidermal cells lose their rectangular appearance, and they start to look flattened (Fig. 5e). At mature tetrad stage, epidermis takes the largest and more flat form, preserving their vitality until the period of anther dehisce (Fig. 5h, i).

The singled layer of endothecium consists of flattened cells at sporogen tissue stage (Fig. 5a). The cells radially elongate (Fig. 5c) and develop until the period of anther dehiscence. However; as from tetrad stage, cells show wall fibrous thickening which increases in the course of cell aging (Fig. $5 \mathrm{e}$ ). At mature pollen stage, endothecial layer and thickening of the wall attain the maximum development (Fig. 5h), and mature pollen grains discharge by dehiscence of stomium, which is the thinnest region of anthers (Fig. 3f and Fig. 2b). Endothecial layer preserves its vitality until the period of anther dehisce like epidermis layer (Fig. 5i).

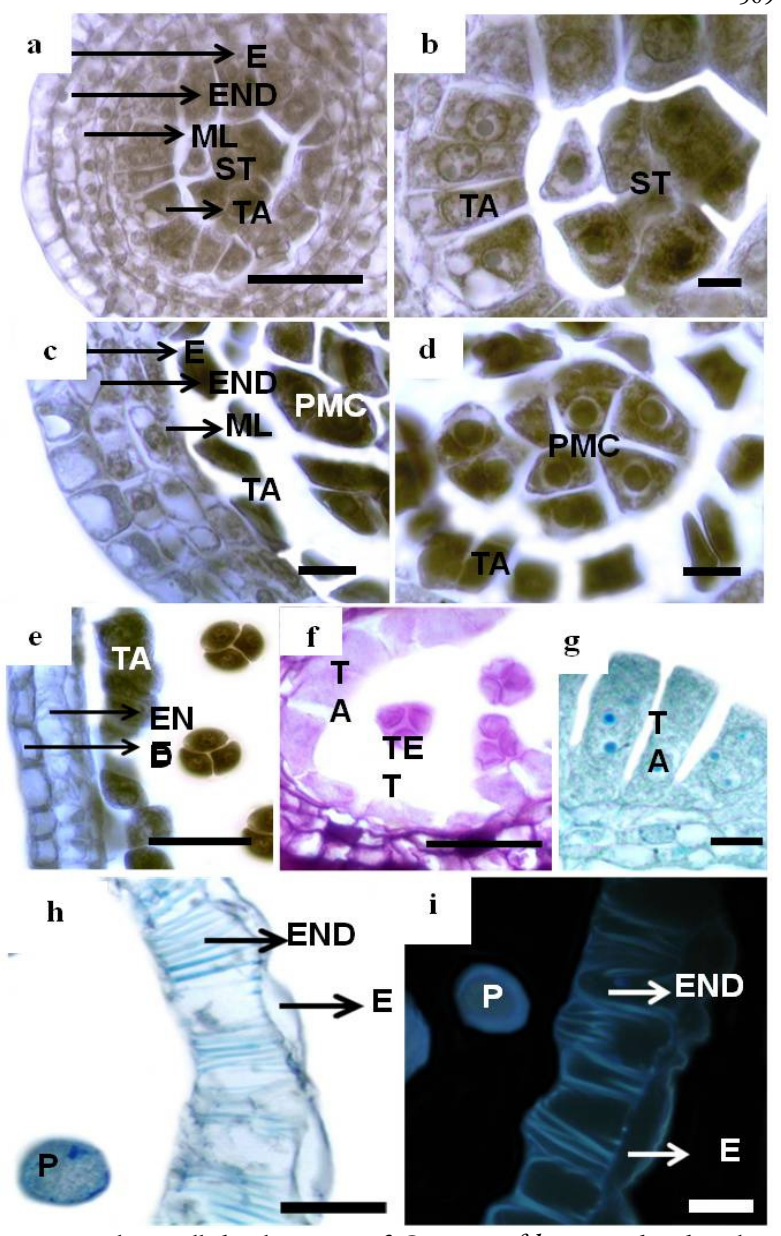

Fig. 5. Anther wall development of C. tanacetifolia. a. Ordered anther wall layers at sporogenous tissue stage. b. Sporogenous tissue and tapetal cells. c. Epidermis and endothecium which become flattened and middle layer showing atrophy at PMCs stage. d. PMCs and tapetal cells starting to extend radially. e. Maximum development of tapetum layer at tetrad stage. f. Tetrads surrounded by callose. g. Tapetal cells extend radially into the anther locus with 2-4 nuclei. h. At mature pollen stage, flattened and thinned epidermal cells and endothecial cells preserving their vitality until the end of the development. i. Endothecial wall thicknening. E: Epidermis, End: Endothecium, ML: Middle Layer, Ta: Tapetum, ST: Sporogenous tissue, PMC: Pollen Mother Cells, TET: Tetrad, P: Pollen. Bar: $50 \mu \mathrm{m}$ (a,e,f,h,i), $10 \mu \mathrm{m}$ (b,c,d)

The middle layer is two-three rows and ephemeral. At sporogen tissue stage, it consists of flattened cells (Fig. 5a). After the first division of the pollen mother cells, middle layer enters a slow atrophy process (Fig. 5c). As from tetrad stage, middle layer cells lose volume (Fig. 5e), and the layer becomes compressed, crushed and completely invisible at mature pollen stage (Fig. 5h, i).

C. tanacetifolia. has secretory tapetum, which consists of single layer of cells (Fig. 5a). They have larger volume, denser cytoplasm and larger spherical nuclei than the rest of cells of the antherwall (Fig. 5b).

Tapetal cells extend radially into the anther locus, from sporogen tissue stage (Fig. 5d) to end of the tetrad stage (Fig. 5e). Until the end of the tetrad stage, width, length and area in the 
510

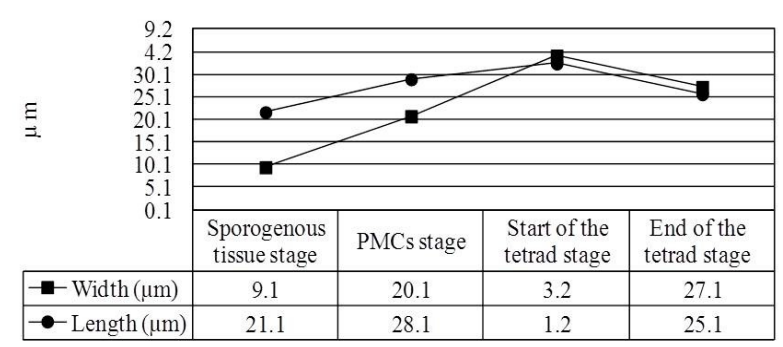

Fig. 6. Width and length of tapetal cells, according to different developmental stages (average 50 cells were measured)

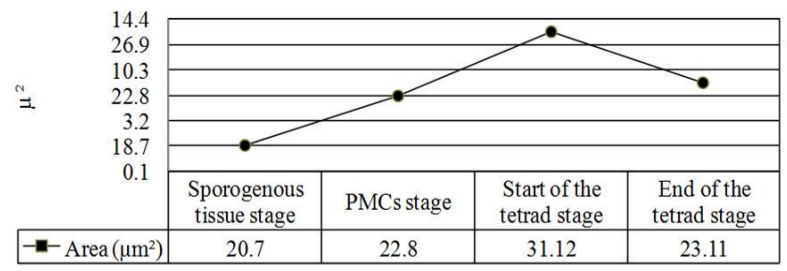

Fig. 7. Area of tapetal cells, according to different development stage (average 50 cells were measured)

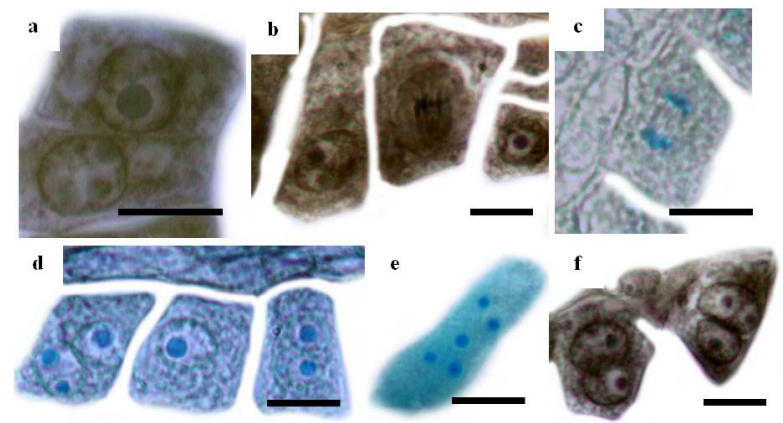

Fig. 8. Observed situations in tapetal cells. a. Tapetal cells with one and two nuclei. b. Metaphase in a tapetal cell. c. Anaphase in a tapetal cell (stained with Coomassie Brillant Blue). d. Tapetal cells with one, two and three nuclei extended radially. e. Giant tapetal nucleus with five nucleoli. f. Nuclear fusion. Bar: $10 \mu \mathrm{m}$

anther locus of tapetal cells increase continuously (Fig. 5f), and cells reach their maximum development in tetrad stage (Fig. 5g). At this stage, cytoplasm of cells gains more density. Since the end of the tetrad stage, cells show a severe reduction in volume by the disintegration of the tapetal vacuoles, and atrophy starts. At young pollen stage, tapetum ruins can be found, however; at mature pollen stage, they completely disappear (Fig. 5h, i). Fig. 6 and Fig. 7 show the width, length and area of tapetal cells, according to different developmental stages.

At sporogenous tissue stage, tapetum cells have usually single nucleus (Fig. 8a). While in the early stages of meiosis at PMCs, tapetal cells have two nuclei. This means that, nuclear division is not followed by cytokinesis. While meiotic division continues in PMCs, mitotic divisions occur in tapetal cells (Fig. 8b, c). As a result, tapetal cells with 2-4 nuclei are observed at tetrad stage (Fig. 8d). Nuclear fusions occur resulting in the formation of giant nucleus with many nucleoli in different sizes in the tapetal cells (Fig. 8e, f). From PMCs stage to tetrad stage, a tapetal cell has centrally located in nucleus. But after tetrad stage, the nucleus is

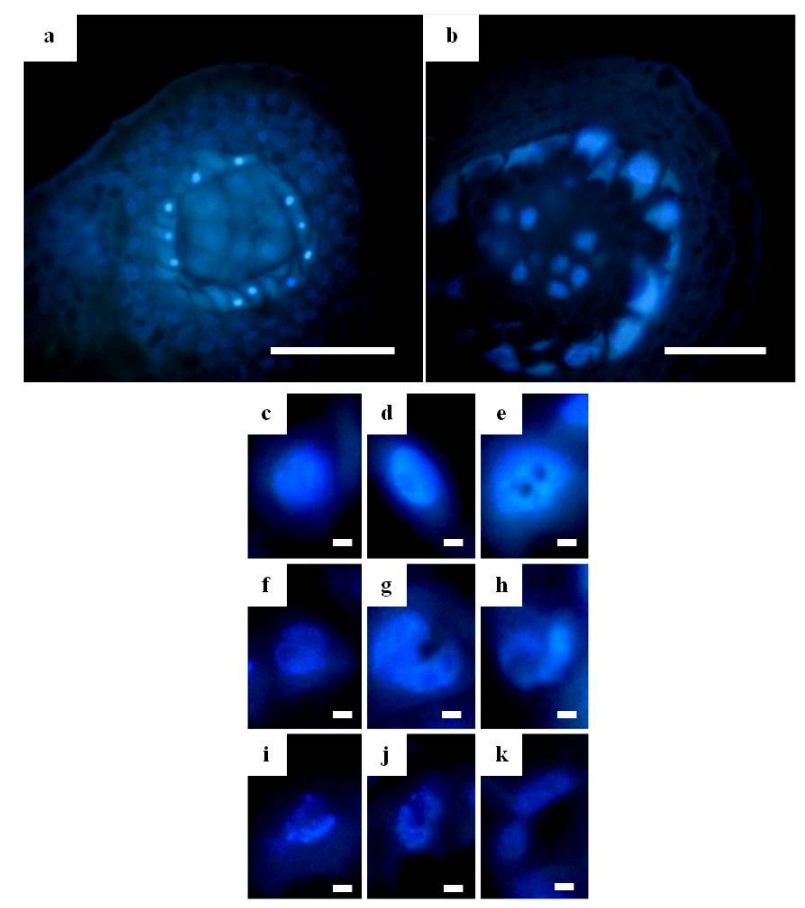

Fig. 9. Nuclear disorders at anther tapetum stained with DAPI. a. Nucleus is ordered, spherical and fluoresces bright blue at sporogenous tissue stage. b. Tapetal cells with degenerated nuclei at tetrad stage. c, d. Nucleus at sporogenous tissue stage. e, f. Nucleus at pollen mother cells stage. g, h, i. Nucleus at start of tetrad stage. j, k. Nucleus at the end of the tetrad stage. Bar: $10 \mu \mathrm{m}(\mathrm{a}, \mathrm{b}), 1 \mu \mathrm{m}(\mathrm{c}-\mathrm{k})$

pushed towards to inner tangential wall of tapetum by a large vacuole, which is formed in this stage.

Tapetum nucleus is stained more bright and intense than nuclei of the other anther wall layers with DAPI. Until the beginning of the tetrad stage, nucleus is ordered, spherical, with blue fluorescence, and nucleolus is distinctive (Fig. 9a, c, d, e, f). From the tetrad stage, disorder in tapetal nucleus starts to be visible (Fig. 9b). Initially, nucleus loses its proper sphere shape, invagination increases and chromatin condenses (Fig. 9g, h, i). At the end of the tetrad stage, with the decrease of the cell volume, the nucleus shrinks. But nucleolus is still evident. In addition, disorders and nuclear fragmentations of nucleus are more apparent. At the end of the this stage (end of tetrad stage - start of young pollen stage), nucleolus disappears, fluorescence of nucleus decreases, and nucleus disintegrates (Fig. 9j, k). Determination of chromatin condensation and nucleus disorders are characteristics of programmed cell death.

\section{Cytochemistry of anther wall layers}

Various cytochemical methods were applied to anthers at different developmental stages. During development, epidermis is rich in insoluble polysaccharides (Fig. 10e-h), but poor in protein and lipid content (Fig. 10a-d and Fig. 10i-l). Endothecium and middle layer are poor in insoluble polysaccharides, proteins and lipids; however, endothecial wall thickenings are rich in these compounds. From tetrad stage, tapetal cells accumulate a large amount of insoluble polysaccharides, proteins and lipids (Fig. 10c, $\mathrm{g}, \mathrm{k}$ ), as well as cells disintegrate at the end of the tetrad stage (Fig. 10d, h, l). 


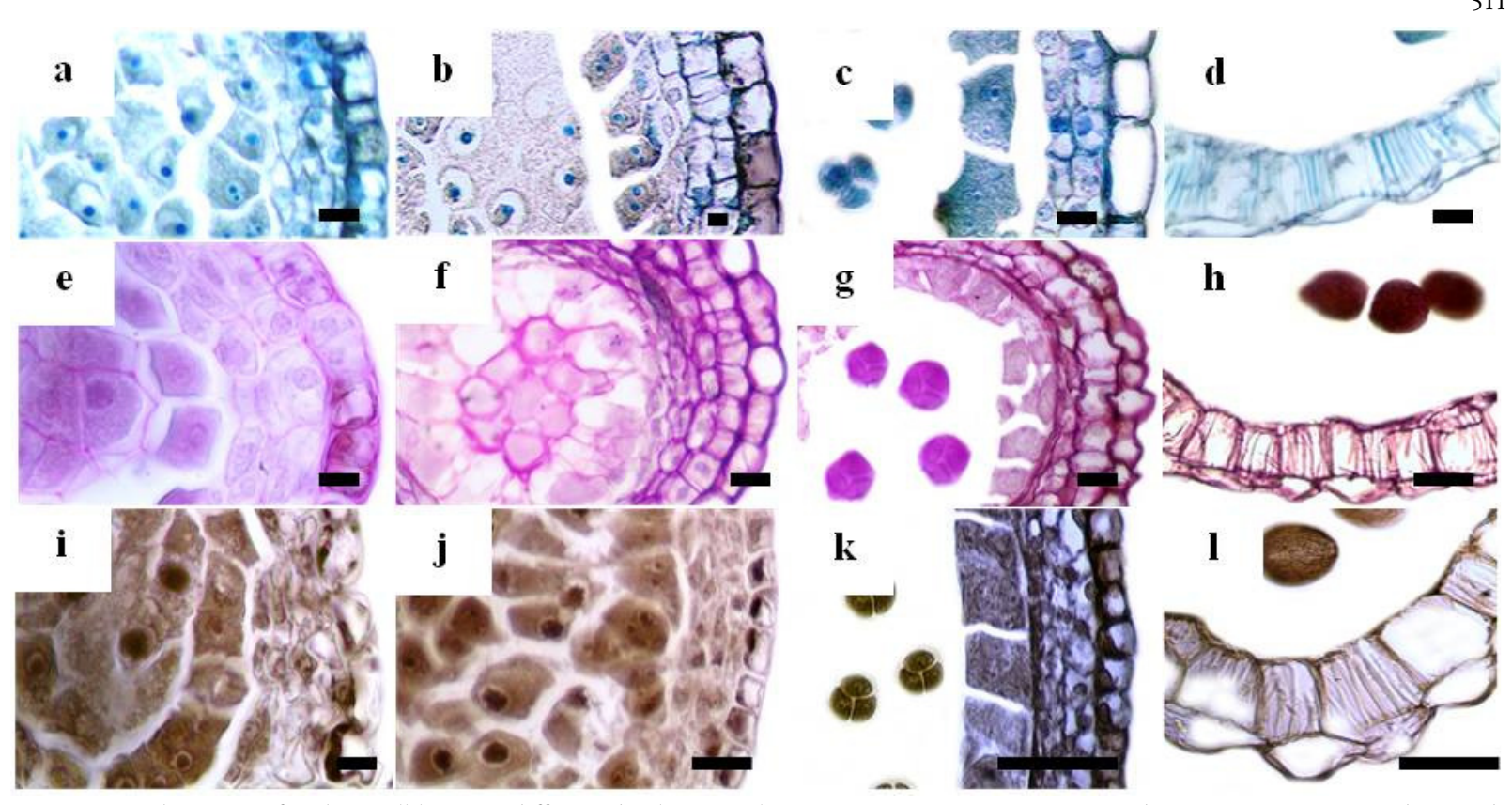

Fig. 10. Cytochemistry of anther wall layers at different developmental stages. a. Sporogenous tissue stage, b. PMCs stage, c. Tetrad stage, d. Mature pollen stage stained with Coomassie Brilliant Blue. e. Sporogenous tissue stage, f. PMCs stage, g. Tetrad stage, h. Mature pollen stage stained with PAS. i. Sporogenous tissue stage, j. PMCs stage, k. Tetrad stage, l. Mature pollen stage stained with Sudan Black B. Bar: $10 \mu \mathrm{m}$ $(\mathrm{a}, \mathrm{b}, \mathrm{c}, \mathrm{d}, \mathrm{e}, \mathrm{i}), 20 \mu \mathrm{m}(\mathrm{f}, \mathrm{g}, \mathrm{j}), 50 \mu \mathrm{m}(\mathrm{h}, \mathrm{k}, \mathrm{l})$

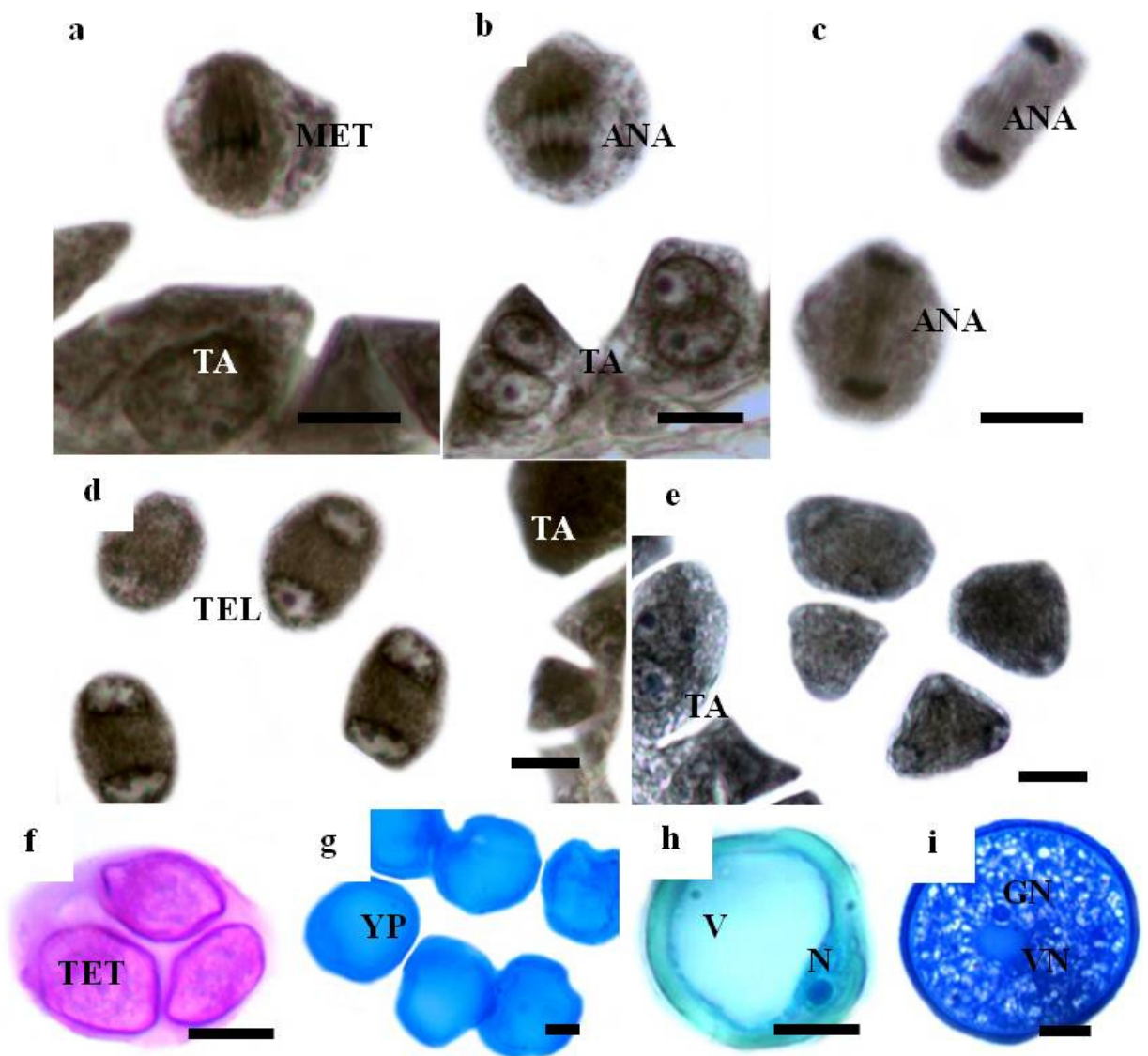

Fig. 11. Some stages of meiosis in the pollen mother cells of $C$. tanacetifolia. a. Metaphase I. b. Anaphase I. c. Late anaphase I. d. Telophase. e. Tetrad formation. f. Tetrahedral tetrad. g. Young pollen. h. Vacuolated pollen. i. Mature two-celled pollen. MET: Metaphase. ANA: Anaphase. TEL: Telophase. TA: Tapetum. TET: Tetrad. YP: Young pollen. V: Vacuole. N: Nucleus. GN: Generative nucleus. VN: Vegetative nucleus. Bar: $10 \mu \mathrm{m}$ 
512

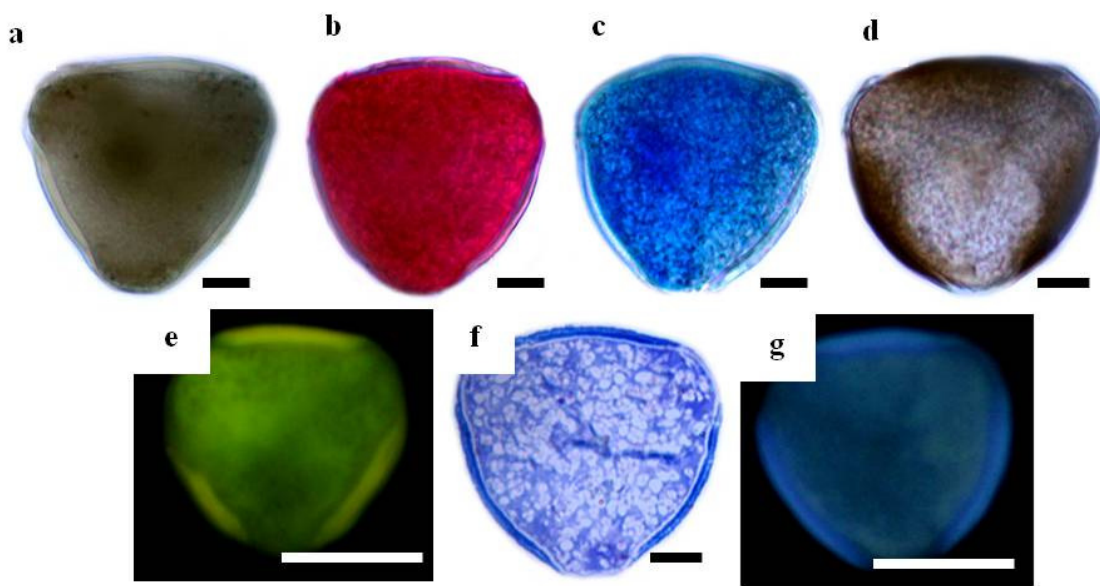

Fig. 12. Pollen morphology and cytochemistry of C. tanacetifolia. a. Stained with hematoksilin, b. PAS, c. Coomassie Brilliant Blue, d. Sudan Black B, e. Auromine O, f. Toluidin Blue, g. DAPI. Bar: $10 \mu \mathrm{m}$

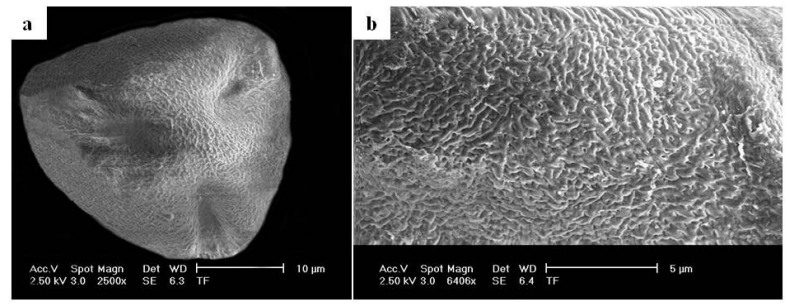

Fig. 13. SEM photomicrographs of C. tanacetifolia's pollen and exine pattern type. a. Pollen grain. b. Rugulate exine pattern. Bar: $10 \mu \mathrm{m}(\mathrm{a}), 5$ $\mu \mathrm{m}(\mathrm{b})$

Table 2. Pollen morphology of $C$. tanacetifolia (E: Width of pollen, P: Height of pollen)

\begin{tabular}{lc}
\hline Pollen Type & Tricolparatae \\
\hline Pollen Shape & Sphaeroidea $($ P/E: $0.96 \mu \mathrm{m})$ \\
Structure & Tectatae \\
Sculptur & Rugulate \\
\hline
\end{tabular}

Table 3. Pollen measurements of $C$. tanacetifolia

\begin{tabular}{lcc}
\hline & Average $(\mu \mathrm{m})$ & Standard deviation $( \pm \mu \mathrm{m})$ \\
\hline Height of pollen & 66.6 & 5.14 \\
Width of pollen & 68.8 & 6.26 \\
Height of pore & 1.58 & 0.97 \\
Width of pore & 18.62 & 2.92 \\
Thickness of exine & 2.04 & 0.54 \\
\hline
\end{tabular}

\section{Microsporogenesis}

Pollen mother cells are isodiametric cells with abundant cytoplasm. They undergo regular meiosis (Fig. 11a-e), forming tetrahedral tetrads surrounding by callose walls (Fig. 11f). At tetrad stage, spores are independent cells, and there is no cellular connection between them. Callose wall is dissolved at the end of meiosis, and young microspores disperse into anther locus. Young microspores are small-volumed cells which have dense cytoplasm without vacuoles and centrally located nuclei (Fig. 11g). When pollen grains start to increase in volume, numerous small vacuoles appear. In the course of development, the small vacuoles fuse to generate a big one (Fig. 11h). The nucleus is pushed towards one side of the pollen grain. At the end of mitosis, two-celled pollen grains are formed; the larger vegetative cell and the smaller generative cell (Fig. 11i).

\section{Morphology and cytochemistry of pollen grains}

In order to determine the pollen morphology, pollen grains were examined by light and scanning electron microscope and the measurements were presented at Table 2 and Table 3.

Pollen grain of $C$. tanacetifolia is tricolporatae, tectatae and sphaeroidea (Fig. 12f and Fig. 13a). The pollen wall is composed of intine, innermost layer and exine, outermost layer (Fig. 12a). Exine of mature pollen grain is thicker than intin and exine pattern is rugulate type (Fig. 13b). Cytoplasm of a mature pollen grain is filled with insoluble polysaccharides, proteins, lipids (Fig. 12b, c, d). Exine is made up of lipoidal substances and proteins (Fig. 12c, d, e, g), but intine is composed of insoluble polysaccharides (Fig. 12b).

\section{Discussion}

In Rosaceae family, anther wall ontogeny and microsporogenesis have been studied in only a few genera (Hamideh et al., 2012; Sumner and Remphrey, 2005). This is the first report on anther wall ontogeny and microsporogenesis in Crataegus tanacetifolia (Lam.) Pers., endemic to Turkey.

In Crataegus species, flowers have usually $10(C$. transmississippiensis) or 20 stamens (C. submollis and C. canadensis) (Phipps, 2012). C. tanacetifolia belongs to the type with 20 stamens.

Generally, one specific type of the anther wall development is found in each family. The anther wall formation in Rosaceae was reported as dicotyledonous type (Davis, 1966). In the study of $C$. babakhanloui (Hamideh et al., 2012), which is a species close to the C. tanacetifolia, anther wall development was reported as dicotyledonous type, and this report is correlated to our study.

Watson and Dallwitz (1992) reported that the members of Rosaceae family have monosporangiate (e.g. Alchemilla), bisporangiate and tetrasporangiate anthers. The anthers of $C$. tanacetifolia are tetrasporangiate.

In most angiosperms, the anther wall consists of four layers from outer to inner: an epidermis, an endothecium, one or two rows of middle layer and tapetum. The outermost cell layer of the anther is epidermis, which in most plants, is slightly modified during development (Rezanejad, 2008) as in C. tanacetifolia. As mentioned by Watson and Dallwitz (1992) in Rosaceae, anther epidermis of $C$. tanacetifolia is persistent and it preserves its vitality until the period of anther splitting as in C. babakhanloui (Hamideh et al., 2012). 
Anther epidermis comprises simple and small cells in C. tanacetifolia. As mentioned by Watson and Dallwitz (1992) in Rosaceae, endothecial cells show wall thicknening in $C$. tanacetifolia. It also preserves its vitality until the period of anther dehisce, as in $C$. babakhanloui (Hamideh et al.,2012).

The row number of middle layer is a taxonomically important character. In Rosaceae, anther wall has more than one middle layer (Watson and Dallwitz, 1992). Although, the middle layer of $C$. babakhanloui consists of two rows (Hamideh et al., 2012), and the number of middle layer in Prunus armenica (Rosaceae) (Julian et al., 2011) is two to four, middle layer in C. tanacetifolia is composed of two or three rows.

The type of tapetum may also have taxonomic value in the sense that all members of most angiosperm families have the same type (Davis, 1966; Johri et al, 1992). Tapetum is identified as secretory type in Rosaceae by Watson and Dallwitz (1992), and it is parallel to this report in C. tanacetifolia. However, C. babakhanloui differs from other species of Rosaceae; by having two types of tapetum, a periplasmoidal type and a secretory type (Bhojvani and Soh, 2010; Hamideh et al, 2012; Lernsten, 2004).

Tapetal classification based on nuclear number (Cooper, 1933) has merit in taxonomy. In Rosaceae, the tapetum is either constantly uninucleate or else binucleate to multinucleate (Buss, 1971). In C. tanacetifolia, at sporogenous tissue stage, a tapetal cell has usually single nucleus with a single nucleolus. While meiosis continues at pollen mother cells, mitotic division occures at tapetal cells, as mentioned by Julian et al. (2011) in Prunus armenica (Rosaceae). Tapetal cells become $2-4$ nucleated at tetrad stage in $C$. tanacetifolia.

The cells of secretory tapetum degenerate towards the end of pollen development (Pacini et al., 1985), and tapetal cells undergo programmed cell death (Papini et al., 1999; Vardar and Unal, 2011; Wu and Cheung, 2000). The time of the degeneration varies greatly among species. Although tapetal cells have completely degenerated at young pollen stage in C. babakhanloui (Hamideh et al., 2012), degeneration progreses rapidly and ends at the end of the tetrad stage in C. tanacetifolia. In Lathyrus undulatus, tapetal cells undergo degeneration at vacuolated pollen stage and completely disappear at bicellular pollen stage (Vardar and Unal, 2011). Programmed cell death takes place in the variety cells of reproductive organs including megaspores, synergids, antipodals, nucellus, suspansor and tapetum. Papini et al. (2014) and Vardar and Unal (2011) demonstrated programmed cell death in the tapetal cells using DAPI, TUNEL and ultrastructural techniques. Vacuolisation, cell shrinkage, chromatin condensation and nuclear degeneration are some of the characteristics of programmed cell death

The tapetum has been considered as the nutritive tissue for the developing pollen (Pacini, 1994). According to our results, the tapetal cells of $C$. tanacetifolia accumulate proteins, carbohydrates and lipoidal substances during development; exclusively at tetrad stage. Cytochemical results of $C$. tanacetifolia anthers showed that the cells of epidermis, endothecium and middle layer give weak reaction to proteins, polysaccharides and lipids. Endothecial thickenings in C. tanacetifolia give intense reaction for proteins, polysaccharides and lipids at mature pollen stage.

In Rosaceae, microsporogenesis is simultaneous (Watson and Dallwitz, 1992) as in C. tanacetifolia. As a result of meiotic division, tetrahedral microspore tetrads are formed in C. tanacetifolia, as in C. babakhanloui (Hamideh et al., 2012). In Rosaceae, pollen grains are shed at 2-celled stage in 14 genera (Watson and Dallwitz, 1992) likewise in C. tanacetifolia.

The general outline of the pollen in the genus Crataegus is usually transversely elliptic in equatorial view and trilobed to subcircular in polar view, as in most other Rosaceae (Byatt, 1976; Eide, 1981; Moore et al., 1991; Reitsma, 1966). In general, there is no significant variation in size between the taxa and within the taxa of Turkish Crataegus (Dönmez, 2008). In C. tanacetifolia, pollen grains are not very big in size. According to Dönmez (2008), the most frequent aperture type is tricolporate in Crataegus taxa, and C. tanacetifolia is correlative to this report.

Several researchers reported that polysaccharides, proteins and lipids exist in pollen cytoplasm (Bedinger, 1992; Hess, 1993; Li $e t$ al., 1995). In C. tanacetifolia, cytoplasm of pollen grains are rich in polysaccharides, proteins and lipids. Exine is made up of lipoidal substances and proteins, but intine is composed of insoluble polysaccharides.

\section{Conclusion}

In Crataegus tanacetifolia, androecium is composed of 20 stamens. Mature anthers are tetrasporangiate and the anther wall formation follows the dicotyledonous type. The anther wall is composed of an epidermis, endothecium, two or three rows of middle layers and secretory tapetum. Epidermal and endothecial layers remain intact until anther dehiscence; however, middle layer and tapetum disappear during development. Tapetum is characterized by enlarged secretory types and chromatin condensation and nucleus disorders are identified in tapetal cells. By regular meiotic division, tetrahedral microspore tetrads are formed. Pollen grains are tricolparatae, tectate and sphaeroidea.

\section{Acknowledgments}

This work was supported by the Research Foundation of Marmara University (BAPKO no. FEN-C-DRP120514-0169).

\section{References}

Aybeke M (2012). Anther wall and pollen development in Ophrys mammosa L. (Orchidaceae). Plant Systematics and Evolution 298(6):1015-1023.

Bedinger P (1992). The remarkable biology of pollen. The Plant Cell 4(8):879-887.

Bhojvani S, Soh WY (2010). Current trends in the embryology of Angiosperms. Springer, Netherlands.

Bittencourt Jr SN (1996). Microsporogenese e etapas da ontogenia do gametofito masculino de Tabebuia ochracea (Cham.) Standley (Bignoniaceae), [Microsporogenesis and the early male gametophyte development of Tabebuia ocbraceae (Cham.) Standley (Bignoniaceae)]. Acta Botanica Brasilica 10(1):9-23.

Buss Jr PA (1971). A survey of tapetal types and tapetal characteristics in the Leguminosae. Retrospective Theses and Dissertations pp. 43-86.

Byatt JI (1976). The structure of some Crataegus populations in northeastern France and South-Eastern Belgium. Watsonia 11(2):105115. 
514

Campbell CS, Evans RC, Morgan DR, Dickinson TA, Arsenault MP (2007). Phylogeny of subtribe Pyrinae (formerly the Maloideae, Rosaceae): limited resolution of a complex evolutionary history. Plant Systematics and Evolution 266:119-145.

Chehregani A, Tanaomi N, Ranjbar M (2008). Pollen and anther development in Onobrychis shabuensis Bornm. (Fabaceae). International Journal of Botany 4(2):241-244.

Cooper DC (1933). Nuclear division in the tapetal cells of certain angiosperms. American Journal of Botany 20(5):358-364.

Davis GL (1966). Systematic embryology of the angiosperms. John Wiley \& Sons Inc, New York.

Davis PH, Browicz K (1972). Flora of Turkey and the East Aegean Islands. Edinburgh University Press.

Dönmez EO (2008). Pollen morphology in Turkish Crataegus (Rosaceae). Botanica Helvetica 118(1):59-70.

Eide F (1981). Key for northwest European Rosaceae pollen. Grana 20(2):101-118.

Feder N, O’Brien TP (1968). Plant microtechnique: Some principles and new methods. American Journal of Botany 55(1):123-142.

Fisher DB, Jensen WA, Ashton ME (1968). Histochemical studies of pollen: Storage pockets in the endoplasmic reticulum. Histochemie 13:169-182.

Galati BG, Rosenfeldt S, Tourn GM (2006). Embryological studies in Lotus glaber (Fabaceae). Annales Botanici Fennici 43:97-106.

Garcia CC (2002). Anther wall formation in Solanaceae species. Annals of Botany 90:701-706.

Gotelli M., Galati B, Hoc P (2006). Embryology of Macroptilium arenarium (Leguminosae). Australian Journal of Botany 54(6):531542.

Hamideh R, Ahmad M, Sedigheh A, Fariba S, Sedigheh M (2012). A study of microsporogenesis and pollen morphology in Crataegus babakhanloui (Rosaceae). Advances in Environmental Biology 6(11):2986-2991.

Hardy CR, Stevensen DW (2000). Development of the gametophyes, flower and floral vasculature in Cochliostema odoratissumum (Commelinaceae). Botanical Journal of the Linnean Society 134:131-157.

Heslop-Harrison Y, Shivanna KR (1977). The receptive surface of the angiosperm stigma. Annals of Botany 41(6):1233-1258.

Hess MW (1993). Membrane coatings on the generative cell surface of freeze-substituted monocotyledon pollen. Protoplasma 176:8488.

Johri BM, Ambegaokar KB, Srivastava PS (1992). Comparative embryology of angiosperms. Springer, Verlag.

Julian C, Rodrigo J, Herrero M (2011). Stamen development and winter dormancy in apricot (Prunus armeniaca). Annals of Botany 108(4):617-625.

Lersten NR (2004). Flowering plant embryology. John Wiley \& Sons.

Li YQ, Southworth D, Linskens HF, Mulcahy DL, Cresti M (1995). Localization of ubiquitin in anthers and pistils of Nicotiana. Sexual Plant Reproduction 8(3):123-128.

Liu CC, Huang TC (2003). Anther and pollen wall development in Dumasia miaoliensis Liu and Lu (Fabaceae). Taiwania 48:273-281.
Moore PD, Webb JA, Collinson ME (1991). Pollen analysis. Blackwell Scientific Publications.

O’Brien TP, Feder N, McCully ME (1964). Polychromatic staining of plant cell walls by toluidine blue. Protoplasma 59(2):368-373.

Pacini E (1994). Cell biology of anther and pollen development. Springer, Netherlands pp 289-308.

Pacini E, Franchi GG, Hesse M (1985). The tapetum: its form, function and possible phylogeny in Embryophyta. Plant Systematics and Evolution 149:155-185.

Papini A, Mosti S, Brighigna L (1999). Programmed cell death events during tapetum development of angiosperms. Protoplasma 207:213-221.

Papini A, Mosti S, van Doorn WG (2014). Classical macroautophagy in Lobivia rauschii (Cactaceae) and possible plastidial autophagy in Tillandsia albida (Bromeliaceae) tapetum cells. Protoplasma 251(3):719-725.

Pearse AG (1961). Histochemistry, theoretical and applied. The American Journal of the Medical Sciences 241(1):136.

Phipps JB (2012). Critical taxa in Crataegus series Molles (Rosaceae): Typifications, new combinations, and taxonomic review. Phytoneuron 78:1-23.

Platt Aloia KA, Oross JW, Thomson WW (1983). Ultrastructural study of the development of oil cells in the mesocarp of avocado fruit. Botanical Gazette 144(1):49-55.

Reitsma TJ (1966). Pollen morphology of some European Rosaceae. Acta Botanica Neerlandica 15(2):290-307.

Rezanejad F (2008). The structure and ultra structure of anther epidermis and pollen in Lagerstroemia indica L. (Lythraceae) in response to air pollution. Turkish Journal of Botany 32(1):35-42.

Schweizer D (1976). Reverse fluorescent chromosome banding with chromomycin and DAPI. Chromosoma 58:307-324.

Strittmatter LI, Galati BG, Monacci F (2000). Ubisch bodies in peritapetal membrane of Abutilon pictum Gill. (Malvaceae). Beitrage zur Biologie der Pflanzen 71:1-10.

Sumner MJ, Remphrey WR (2005). Microsporogenesis in Amelanchier alnifolia: sporogenous cells, microsporocytes, and tetrads. Botany 83(9):1106-1116.

Topçuoğlu N, Selvi N, Dokumaci E (2009). The comparison of critical point drying and drying withhexamethyldisilazane methods for the preparation of mice tissues for scanning electron microscopy ii. Lung and stomach findings. Anadolu University Journal of Science and Technology 1:127-132.

Vardar F, Unal M (2011). Cytochemical and ultrastructural observations of anthers and pollen grains in Lathyrus undulatus Boiss. Acta Botanica Croatica 70(1):53-64.

Watson L, Dallwitz MJ (1992). The families of angiosperms: Automated descriptions, with interactive identification and information retrieval. Australian Systematic Botany 4(4):681695.

Wu HM, Cheung AY (2000). Programmed cell death in plant reproduction. Springer, Netherlands pp 23-37. 